\title{
Paradigma Keilmuan Islam
}

\author{
Maryamah ${ }^{1}$, Ahmad Syukri $^{2}$, Badarussyamsi ${ }^{3}$, Ahmad Fadhil Rizki ${ }^{4}$ \\ ${ }^{1}$ Mahasiswa Pascasarjana Universitas Islam Negeri Sulthan Thaha Saifuddin Jambi, Indonesia \\ 2,3Jurusan Manajemen Pendidikan Islam UIN Jambi, Indonesia \\ ${ }^{4}$ Pendidikan Agama Islam STAI Miftahul Tanjungpinang, Indonesia \\ E-mail:maryamah.ama.pd@gmail.com¹, ahmadsyukriss@uinjambi.ac.id². \\ badarussyamsi@uinjambi.ac.id³. Ahmadfadhilrizki1995@gmail.com4.
}

\begin{abstract}
Abstrak
Paradigma keilmuan Islam membahas tentang cara pandang Islam terhadap ilmu pengetahuan berdasarkan sumber alqur'an yang diyakini kebenarannya, belakangan terjadi dikotomi antara ilmu agama dan ilmu umum. IImu agama berbicara seputar hubungan manusia dengan Tuhan dan manusia dengan manusia dalam kehidupan sosial. Ilmu umum juga berbicara banyak tentang alam semesta. Melaui jenis penelitian pustaka dengan pendekatan kualitatif ditemukan bahwa keduanya disinergikan dengan penemuan-penemuan fakta ilmiah melalui para ilmuan Barat dan Muslim sehingga berpendapat bahwa ilmu dan agama merupakan satu kesatuan yang tidak bisa dipisahkan. Keduanya saling keterkaitan memberikan penjelasan kepada manusia tentang ilmu pengetahuan. Seni sebagai hasil kreativitas manusia adalah suatu keindahan estetika dan memberi nilai dari sebuah ilmu maupun agama sehingga menjadi sesuatu yang bernilai untuk keberlangsungan kehidupan manusia baik itu dari aspek ilmu pengetahuan, sosial, dan budaya dalam suatu peradaban dunia.
\end{abstract}

Kata kunci: paradigma; keilmuan; Islam.

\begin{abstract}
The Islamic scientific paradigm discusses the Islamic perspective on science based on the source of the Koran which is believed to be true, recently there has been a dichotomy between religious science and general science, religious science talks about the relationship between humans and God and humans and humans in social life, and general science talks about a lot about the universe. through the type of literature research with an approach approach, it was found that both were synergized with the discovery of scientific facts through western and Muslim scientists so that they argued that science and religion were an inseparable unity, interrelated to provide explanations about humans. Art as a result of human creativity is an aesthetic beauty and gives value to a science or religion so that it becomes something that is feasible for human survival both from the scientific, social, and cultural aspects in a world civilization.
\end{abstract}

Keywords: paradigm; science; Islam.

\section{Pendahuluan}

Kehidupan manusia hingga saat ini terus berkembang. Hal tersebut dapat dilihat dengan berkembangnya ilmu pengetahuan. Seiring dengan rasa ingin tahu yang tinggi pada seseorang dan mendorongnya untuk melakukan penelitian serta menemukan suatu ilmu pengetahuan yang baru. Di sisi lain, perkembangnan ilmu yang sangat cepat dapat mendorong munculnya kompartementalisasi yang tidak sehat antara satu bidang ilmu dengan yang lainnya. Namun hal tersebut kini menjadi tugas filsafat untuk menyatukan visi keilmuan itu sendiri agar tidak terjadi bentrokan antara satu dengan yang lainnya.

IImu merupakan sesuatu yang paling penting bagi manusia, karena dengan ilmu semua keperluan dan kebutuhan manusia bisa terpenuhi secara lebih cepat dan lebih mudah. Dengan kemajuan ilmu juga manusia dapat merasakan kemudahan lainnya. Seperti transportasi, pemukiman, pendidikan, komunikasi, dan lain sebagainya.

Terdapat suatu persoalan yang perlu di perhatikan yakni terjadi dikotomi atau pemisahan antara ilmu dan agama. Ada yang berpendapat ilmu berbeda halnya dengan agama demikian pula sebaliknya dan bahkan lebih parah dari itu, ada yang mengatakan ilmu tidak dapat disatukan dengan agama. dengan munculnya istilah shifting paradigm dalam ilmu fisika alam oleh Thomas S. Kuhn dan dalam ilmu-ilmu keislaman oleh Amin Abdullah, misalnya dari kerja heuristic filsafat ilmu.

Padahal jika ditelaah lebih jauh lagi, munculnya ilmu-ilmu pengetahuan yang ada hari ini telah disampaikan dalam sumber ilmu yang menjadi pedoman pada umat Islam yakni Al-qur'an sejak 1400 tahun lalu. Islam bukan sekadar agama, tetapi Islam merupakan sumber dari berbagai ilmu pengetahuan yang ada. Umat muslim tinggal mengkaji satu demi satu yang ada dalam alqur'an untuk ditelaah dan 
dilakukan penelitian untuk mendapatkan kebenarannya. Tetapi yang terjadi saat ini justru penemuanpenemuan ayat yang berkaitan dengan ilmu pengetahuan bukan dari kalangan umat muslim, melainkan para ilmuan nonmuslim yang giat menggali dengan ingin tahu makna dibalik sebuah ayat. Semakin digali semakin pula teruji kebenaran tersebut, semakin para peneliti ingin melemahkan alqur'an justru semakin la mendapatkan kebenaran yang tidak terbantahkan dalam alqur'an. Itu semua adalah kehendak dan kekuasaan Allah Subha Nahuwa Ta'ala. Kita sebagai manusia tentu wajib mempercayainya karena alqur'an selain menjadi sumber ilmu pengetahuan juga menjadi pedoman hidup umat muslim hingga akhir kehiduan.

Dari permasalahan yang terjadi tersebut, sejatinya yang perlu diktahui adalah seorang ilmuan secara moral tidak akan membiarkan hasil penelitiannya atau penemuannya dipergunakan untuk menindas bangsa lain meskipun yang mempergunakan adalah bangsanya sendiri. Pengetahuan merupakan kekuasaan, kekuasaan yang dapat dipakai untuk kemaslahatan manusia atau sebaliknya dapat disalahgunakan. Untuk itu tanggungjawab ilmuan harus "dipupuk" dan berada dalam tempat yang tepat, tanggung jawab akademis dan tanggung jawab moral.

Dengan ilmu pengetahuan manusia dapat menikmati transportasi yang cepat dengan jarak tempuh yang tidak dekat, kemudian manusia juga bisa menikmati berbincang secara leluasa satu dengan lainnya meski berjauhan bahkan dapat melihat langsung lawan bicaranya melalui layar gawai atau laptop. Hal tersebut bukanlah suatu hal yang baru, khususnya dalam agama Islam, telah ada sejak 1400 tahun lalu dalam sebuah kejadian yang luar biasa yang ditempuh oleh Rasulullah dalam perjalanan Isra' Mi'raj nya. Hanya saja pada masa itu bagi manusia yang tidak mempercayainya tentu saja menganggap itu hanya sebuah dongeng, karena diukur dengan kemampuan akal manusia bahwa tidak mungkin dalam waktu satu malam Rasulullah dapat menempuh perjalanan dari masjidil Haram (Mekah) ke masjidil Aqsa (Palestina) dan kemudian naik ke langit pertama sampai langit ketujuh dan bahkan sampai ke sidratul muntaha hanya dengan kendaraan yang dinamai buraq. Tetapi ketika melihat perkembangan teknologi hari ini, maka peristiwa besar isra' mi'raj tersebut tidak lagi menjadi suatu yang mustahil, karena saat ini jarak tidak lagi menjadi kendala untuk bisa saling sapa antara satu dengan yang lainnya, cukup dengan satu kali klik maka kita bisa melihat dunia luar yang terjauh sekalipun. Allahu'alam.

Dari kejadian tersebut, jelas terbukti pentingnya suatu ilmu pengetahuan, karena dengan ilmu manusia dapat "menguasai" dunia. Dalam Alqur'an, Allah SWT juga memberikan motivasi kepada manusia untuk semangat menuntut ilmu, seperti yang termuat dalam surah ar-rahman ayat 33 Allah berfirman yang artinya "Hai jamaah Jin dan Manusia, jika kamu sanggup menembus (melintasi) penjuru langit dan bumi, maka tembusilah, kamu tidak akan dapat menembusnya kecuali dengan kekuatan". Dari ayat tersebut, menurut Tafsir Ibnu Katsir dalam kitab Ibnu Katsir mengatakan bahwa, manusia maupun jin tidak akan sanggup lari dari takdir Allah bahkan malaikat berdiri tujuh lapis mengelilingimu, dan kamu tidak dapat lari dari pada-Nya kecuali atas kehendak Allah.

Ayat tersebut memberi isyarat ilmiah kepada bangsa jin dan manusia, bahwa Allah telah mempersilakan untuk menjelajahi angkasa luar, asalkan mereka memiliki kekuatan. Maksud dari kekuatan dari ayat tersebut sebagaimana ditafsirkan oleh para ulama adalah ilmu pengetahuan atau sains dan teknologi (l'anatut Thoifah, 2020: 152).

Munculnya ilmu pengetahuan tidak lepas dari sebuah paradigma yang ada tentang ilmu tesebut. Berbagai paradigma dan setiap paradigma akan menjawab persoalan yang ada dan akan memberikan solusi terhadap permasalahan tersebut.

Melihat dari berbagai fenomena dan paradigma yang terjadi terkait kelimuan Islam, maka peneliti memandang penting dilakukan penelitian untuk mengajak kita berpikir lebih kritis terhadap pemisahan ilmu tersebut serta cara agar permasaalahan yang terjadi dapat ditemukan solusinya, karena antara ilmu agama dan ilmu umum bukanlah suatu hal yang harus diperdebatkan melainkan suatu hal yang dapat disatukan. Keduanya seperti dua sisi mata uang yang tidak dapat dipisahkan. Perbedaan sudut pandang seharusnya tidak menjadi kedua ilmu tersebut semakin berjauhan justru berbagai sudut pandang akan menemukan jalan keluar dan menyatukannya sehingga menjadi keilmuan yang utuh dan bermafaat bagi kehidupan.

Sejalan dengan hal tersebut, Afrinaldi, Toha Andiko, dan Taufiqurrahman juga menyebutkan dalam jurnalnya yang berjudul "The Paradigm of Science Integration in Islamic University: The Historicity and Development Pattern of Islamic Studies in Indonesia" bahwa dalam praktiknya, pelaksanaan integrasi keilmuan diterapkan pada fakultas melalui kebijakan langsung dari universitas. Secara umum, Perguruan Tinggi Islam di Indonesia telah memiliki paradigma filosofis, dengan mengusung konsep integrasi keilmuan yang khas. Dalam aspek penjabaran paradigma integrasi tersebut, tercermin dalam kurikulum yang diterapkan. Namun, dari penjabaran integrasi keilmuan sesungguhnya ingin memadukan disiplin ilmu keagamaan dengan teknologi dan sains modern, yang diimplementasikan dalam pendidikan tinggi Islam di Indonesia. Dalam pengembangan konsep integrasi keilmuan di masing-masing UIN Indonesia memiliki keragaman redaksional dan elaborasi yang sangat kontekstual dengan lingkungan dan kultur daerah masing-masing. Hal tersebut menggambarkan bahwa dikotomi antara ilmu agama dan ilmu umum 
Jurnal Filsafat Indonesia, Vol 4 No 2 Tahun 2021

ISSN: E-ISSN 2620-7982, P-ISSN: 2620-7990

dapat disatukan dan menjadi disiplin ilmu yang modern.

\section{Metode Penelitian}

Penelitian menggunakan jenis pustaka (library research) dengan pendekatan kualitatif, merupakan penelitian yang menggunakan cara untuk mendapatkan data informasi dengan menempatkan fasilitas yang ada di perpustakaan, seperti buku, dokumen, majalah, catatan/tulisan kisah-kisah sejarah atau penelitian kepustakaan murni yang terkait dengan objek penelitian. (Mahmud, 2011: 31).

Model pendekataan content analysis (kajianisi), penelitian ini bersifat pembahasan yang mendalam terhadap isi suatu informasi tertulis atau tercetak dalam media massa. Analisis ini biasanya digunakan pada penelitian kualitatif. content analysis (kajian isi) secara umum diartikan sebagai metode yang meliputi semua analisis mengenai isi teks, tetapi di sisi lain analisis isi juga digunakan untuk mendeskripsikan pendekatan analisis khusus. (Rahman Sholeh, 2005: 63).

Dalam penelitian kepustakaan (library research) ini, sumber data yang merupakan bahan tertulis terdiri atas sumber data primer dan sumber data sekunder sebagai berikut.

a. Sumber data primer

Sumber data primer, yaitu data yang diperoleh langsung dari subjek penelitian sebagai sumber informasi yang dicari. Data ini disebut juga dengan data tangan pertama atau data yang langsung yang berkaitan dengan objek riset. Sumber data dalam penelitan ini adalah buku filsafat yang membahas mengenai Paradigma Keilmuan Islam baik secara global maupun tidak.

b. Sumber data sekunder

Sumber data sekunder merupakan data yang diperoleh lewat pihak lain, tidak langsung diperoleh oleh peneliti dari subjek penelitiannya.

Fokus dalam penelitian ini adalah Paradigma Keilmuan Islam. Adapun teknik dalam mengumpulkan data dalam penelitian ini adalah menggabungkan semua referensi yang membahas tentang Paradigma Keilmuan Islam.

Analisis data adalah proses mencari dan menyusun secara sistematis data yang diperoleh. Analisis data dilakukan dengan mengorganisasikan data, menjabarkan ke dalam unit-unit, melakukan sintesa, menyususn kedalam pola, memilih mana yang penting dan yang akan dipelajari, dan membuat kesimpulan yang dapat diceritakan kepada orang lain.

Penelitian ini bertujuan sebagai menambah khazanah kelilmuan kita terhadap disiplin ilmu khususnya filsafat ilmu yang membahas tentang berbagai persoalan kehidupan dan menjadi salah satu focus penelitian adalah bagaimana paradigma keilmuan Islam yang terjadi di kalangan keilmuan serta dampaknya dalam dunia pendidikan serta bagaimana upaya dan langkah-langkah yang dapat dilakukan untuk memperbaiki paradigma lama terkait dikotomi keilmuan yang cendrung terjadi di kalangan ilmuan dan kalangan akademis saat ini.

\section{Pembahasan}

\section{a. Paradigma Keilmuan Islam}

Sejak dulu hingga saat ini, perkembangan dunia keilmuan semakin maju dan berkembang, hal tersebut dapat dilihat dengan berbagai macam temuan ilmuan dalam mengupas berbagai persoalan dan pertanyaan mendasar seputar kehidupan, mulai dari ilmuan Barat hingga ke Timur fokus mencari faktafakta ilmiah hal-hal tentang ilmu pengetahuan itu sendiri. Paradigma keilmuan Islam merupakan suatu kajian yang sangat berkaitan erat dengan sudut pandang dalam memahami permasalahan yang terjadi. Munculnya paradigma merupakan hasil dari penelitian ilmiah yang dilakukan secara mendalam hingga pada akhirnya menemukan suatu hal yang baru hingga muncul pula paradigma baru terhadap hal tersebut. Dalam sudut pandang Islam, mempelajari suatu ilmu merupakan suatu ibadah kepada Allah dan terdapat beberapa matlamat tertentu dalam proses menuntut ilmu. Ilmu juga mengizinkan manusia mengkaji alam semesta ciptaan Allah ini. Untuk kehidupan dunia kita memerlukan ilmu yang dapat menopang kehidupan dunia, untuk persiapan di akhirat. Lalu bagaimana jika ilmu agama dipisahkan dengan ilmu umum? Sedangkan umat Islam meyakini bahwa semua cabang ilmu sumbernya adalah satu yakni Allah SWT sebagai Tuhan semesta alam yang menciptakan segala sesuatunya. Hal tersebut tidak diyakini oleh para ilmuan Barat karena sebagian dari IImuan barat berpendapat bahwa ilmu dapat ditemukan dengan melakukan pencarian secara ilmiah dan mengingkari adanya Tuhan sebagai sumber utamanya. Oleh karena itu penting untuk ditelaah lebih jauh lagi sikap kita untuk memahami hal tersebut sehingga tidak terjadi pemisahan antara ilmu agama dan ilmu umum.

\section{b. Konsep Dasar Paradigma}

Kata paradigma bukan suatu kata yang baru, meski jarang digunakan dalam percakapan seharihari, tetapi jauh sebelum kita lahir kata tersebut sudah sering didengar dan digunakan oleh orang lain 
terutama para ilmuan dalam mengembangkan ilmunya. Kata paradigma itu sendiri diperkenalkan kali pertama oleh seorang ilmuan Thomas Kuhn dalam bukunya yang berjudul The Structure of Scientific Revolution. Namun dalam buku tersebut tidak dijelaskan secara eksplisit makna dari paradigma tersebut. Thomas Kuhn hanya menggunakan kata paradigma sebagai termonologi kunci yang dipakai dalam model perkembangan ilmu pengetahuan saja. Istilah paradigma baru terdefinisi secara jelas oleh Robert Fridrichs sebagai orang pertama yang mengungkapkan definisi paradigma.

Muncul sebuah pertanyaan, apa itu paradigma? Setiap orang berusaha membuat definisi masingmasing sesuai dengan yang diketahui. Paradigma sejatinya berkaitan erat dengan prinsip-prinsip dasar yang menentukan berbagai macam pandangan manusia terhadap dunia sebagai bagian dari sistem bricouler.

Secara etimologis, kata paradigma berasal dari bahasa Yunani dari kata "para" yang artinya di sebelah atau di samping, dan "diegma" artinya teladan, ideal, model, ataupun arketif. Sedangkan secara terminologi diartikan sebagai sebuah pandangan ataupun cara pandang yang digunakan untuk menilai dunia dan alam sekitarnya.

Thomas Kuhn dalam I.B. Wirawan mendefinisikan paradigma sebagai pandangan yang mendasar tentang apa yang menjadi pokok persoalan dalam ilmu pengetahuan tertentu (Wirawan, 2012: 1). Pandangan lain, paradigma adalah jendela keilmuan yang dapat digunakan untuk "melihat" berbagai persoalan yang terjadi dalam dunia sosial. Tinggal tingkat kejernihan dari sebuah "jendela ilmu" tersebut untuk dapat digunakan sehingga sangat berpengaruh terhadap pemahaman seseorang tentang apa dan bagaimananya.

Paradigma juga diartikan sebagai kerangka berpikir ilmiah. IImu membutuhkan kerangka berpikir yang tajam, penelitian juga membutuhkan paradigma berpikir. Dalam proses keilmuan, paradigma keilmuan memegang peranan yang penting. Fungsi paradigma memberikan kerangka, mengarahkan, bahkan menguji konsistensi dari proses keilmuan (Suwardi, 2012: 234).

\section{c. Hubungan Worldview dengan Paradigma}

Paradigma juga disejalankan dengan worldview (pandangan hidup). Hubungan keduanya adalah seperangkat keyakinan mendasar yang memandu tindakan kita, baik tindakan keseharian maupun tindakan ilmiah (Thomas Kuhn), sedangkan worldview adalah asas bagi setiap prilaku manusia, termasuk aktivitas-aktivitas ilmiah dan teknologi. Setiap aktivitas manusia akhirnya dapat dilacak pada pandangan hidupnya (Prof. Alparslan)

Paradigma ilmu merupakan seperangkat keyakinan dasar untuk mengungkapkan hakikat ilmu dan cara mendapatkannya, hal tersebut terdiri atas 5 (lima) pertanyaan mendasar yakni (Suwardi, 2012: 236).

1) Ontologis; yakni hakikat sesuatu yang dapat diketahui.

2) Epistimologis; yakni hubungan subjek dan objek ilmu.

3) Aksiologis; yakni peran nilai dalam penelitian.

4) Retorik; yakni bahasa dalam penelitian.

5) Metodologis; yakni tentang bagaimana metode mencari dan menemukan kebenaran ilmu.

Bila diiuraikan lagi, paradigma memiliki beberapa arti yakni sebagai berikut.

1) Cara memandang sesuatu.

2) Dalam ilmu pengetahuan: model, pola, ideal. Dari model-model inilah fenomena dipandang, dijelaskan.

3) Totalitas premis-premis teoritis dan metodologis yang menentukan atau mendefinisikan suatu studi ilmiah konkret.

4) Dasar untuk menyeleksi problem-problem dan pola untuk memecahkan problem-problem riset. (Khusnul Khotimah, 2014: 4).

Dalam pertemuan diskusi profetik masjid kampus UGM dengan pembicara Prof. Dr. Heddy Shri Ahimsa-Putra, MA, M. Phil dengan tema "Islam as a Scientific Paradigm" menjelaskan bahwa selama ini Islam lebih dipahami sebagai paradigma untuk kehidupan "beragama" yang hanya mengatur kehidupan sosial dan spiritual, hanya sebatas hubungan manusia dengan Tuhannya dan manusia dengan sesamanya. Akibatnya jarang didapatkan pada buku-buku ilmiah yang menerangkan bahwa alqura'an dan hadist juga merupakan sumber inspirasi dan sumber pengetahuan bagi manusia dalam mengeksplor kehidupan dunia. Justru yang terjadi dan sering dipertontonkan adalah upaya pemisahan antara agama dan ilmu pengetahuan dan terus berlanjut sehingga menjadi dikotomi antara keduanya. Oleh karena itu, integrasi sains dan agama hanya bisa dilakukan dengan cara mengubah cara pandang, mengubah "paradigma" bahwa Islam tidak hanya persoalan manusia dengan Tuhannya saja atau manusia dengan sesamanya saja tetapi jauh dari itu dipahami bahwa Islam merupakan pengetahuan untuk semua aspek kehidupan manusia.

Islam tidak hanya persoalan manusia dengan sesama tetapi lebih dari itu Islam untuk 
pengembangan ilmu pengetahuan. Bila kita memandang Islam sebagai ajaran, maka akan sangat banyak hal-hal yang didapatkan dari Islam itu sendiri mulai dari ilmu pengetahuan yang bersumber alqur'an dan tafsir-tafsirnya, hadits dan tafsir-tafsirnya, kitab-kitab karya para ulama dan berbagai pandangan para ilmuan muslim yang dapat menambah khazanah ilmu pengetahuan manusia.

Paradigma juga dapat diartikan sebagai kerangka teori atau kerangka berpikir tetapi paradigma lebih umum dan lebih abstrak karena itu merupakan kerangka logis dari teori sehingga satu paradigma bisa mencakupi beberapa teori, dalam kaitannya dengan Islam sebagai paradigma kerangka teori atau kerangka berpikir juga cendrung pada ke-Islaman itu sendiri. Seperti contoh ketika menghadapi pandemi covid, dengan kerangka berpikirnya orang Islam maka seseorang akan berpikir dan menghubungkan pandemi tersebut dengan ibadahnya, hubungannya dengan Rabbnya, namun di sisi lain cara pandang orang lain mungkin saja berbeda sesuai dengan paradigma yang dimiliki tentang hal persebut.

Maka apabila Islam sebagai paradigma, seorang muslim akan memiliki sistem pengetahuan islam yang terdiri atas alqur'an, hadis, pendapat para sahabat, ulama, dan ilmuan muslim sebagai acuan kerangka teorinya untuk berpikir, memahami, menafsirkan, dan menjelaskan masalah-masalah kenyataan hidup yang sedang dihadapinya. Dalam kaitannya dengan sains, sistem pengetahuan tersebut menjadi sumber inspirasi untuk mengatasi berbagai macam permasalahan yang terjadi termasuk di dalamnya adalah ilmu pengetahuan.

Melihat dari hal tersebut, maka paradigma juga dapat diartikan sebagai seperangkat konsep yang berhubungan satu sama lain secara logis, membentuk sebuah kerangka pemikiran yang berfungsi untuk memahami, menafsirkan, dan menjelaskan kenyataan dan/atau masalah yang dihadapi (Ahimsa Putra: 2009). Paradigma sebagai seperangkat unsur-unsur berupa konsep, unsur-unsur saling berhubungan, dan hubungan pada tataran logika (pikiran). berikut.

Selain itu terdapat beberapa karakteristik epistimologi Islam dan Barat yang jika ditabelkan sebagai

Tabel 1. Karakteristik Epistimologis Islam dan Barat

\begin{tabular}{|c|c|}
\hline Islam & Barat \\
\hline Asas & Asas \\
\hline $\begin{array}{l}\text { Pandangan hidup Islam berdasarkan wahyu, } \\
\text { hadist, akal, pengalaman dan intuisi. }\end{array}$ & $\begin{array}{l}\text { Wordlview Barat berdasarkan rasio dan } \\
\text { spekulasi filosofis }\end{array}$ \\
\hline Pendekatan: Tawhidi & Pendekatan: Dichotomis \\
\hline Sifat: & Sifat: \\
\hline $\begin{array}{l}\text { Rasional, metafisis, dan supra-rasional, ada } \\
\text { yang permanen dan ada yang berubah. }\end{array}$ & $\begin{array}{l}\text { Rasional, non-metafisis, terbuka dan selalu } \\
\text { berubah. }\end{array}$ \\
\hline Makna realitas dan kebenaran: & Makna realitas dan kebenaran: \\
\hline $\begin{array}{l}\text { Al-haqq dan al-haqiqah, berdimensi metafisik } \\
\text { dan fisik, rasional }\end{array}$ & $\begin{array}{l}\text { Truth berdimensi sosial, kultural, empiris, } \\
\text { rasional. }\end{array}$ \\
\hline $\begin{array}{l}\text { Objek kajian: invisible \& visible, ('alam al- } \\
\text { mulk, \& al-syahadah. }\end{array}$ & Objek kajian: realitas empiris, non- \\
\hline
\end{tabular}

Paradigma memiliki unsur-unsur yang satu sama lain saling berhubungan, terdapat 9 (Sembilan) unsur sebagaimana dimaksud diantaranya adalah (Ahimsa Putra: 2009).

1) Asumsi dasar (basic assumptions).

2) Nilai-nilai (values).

3) Model (analogy; perumpamaaan).

4) Masalah yang diteliti (problems).

5) Konsep-konsep (concepts; key words).

6) Metode penelitian (methods of research).

7) Metode analisis (methods of analysis).

8) Teori (theory).

9) Representasi (representation). 
Dari Sembilan unsur tersebut jika digambarkan dalam bentuk skema menjadi sebagai berikut.

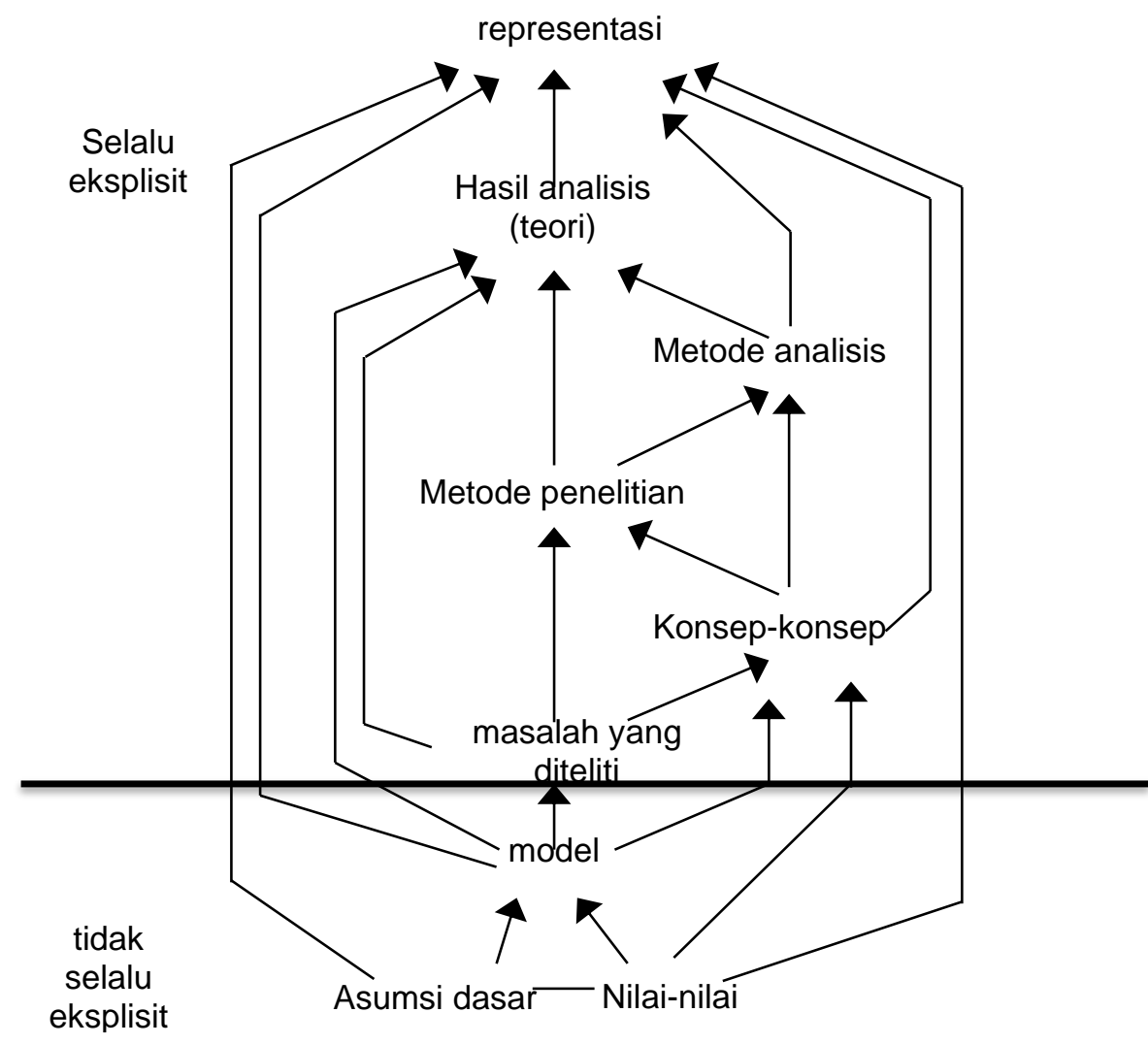

Sumber: Ahimsa-Putra 2009

\section{Gambar.1 Skema Unsur-Unsur Paradigma}

Dari skema di atas menggambarkan bahwa dalam sebuah paradigma yang terdiri atas sembilan unsur tersebut terdapat bagian-bagian yang selalu eksplisit dan tidak selalu eksplisiit. Unsur yang tidak selalu eksplisit terdiri atas tiga elemen yakni asumsi dasar, nilai, dan model. Nilai dalam pembahasan filsafat merupakan kualitas empiris yang tidak dapat didefenisikan (Louis O. Kattsoff, 2018: 325). Ketiga elemen tersebut tidak selalu kita sadari. Sedangkan elemen yang selalu eksplisit dapat diuraikan seperti elemen "masalah yang diteliti" sebagaimana yang dikatakan oleh Thomas Kuhn bahwa setiap paradigma berusaha menjawab pertanyaan tertentu, apabila terdapat pertanyaan yang tidak bisa dijawab oleh paradigma tersebut, maka akan muncul paradigma baru, dan setiap paradigma memiliki permasalahannya sendiri-sendiri. Paradigma baru biasanya akan muncul setelah dilakukan penelitian dan hal tersebut tidak bisa dijawab oleh paradigma yang digunakan sebelumnya. Sehingga upaya untuk menjawab permasalahan tersebut maka muncullah paradigma yang baru. Oleh karena itu, dalam elemen di atas, masalah yang diteliti menjadi suatu elemen yang sangat penting dalam unsur paradigma yang ada. Dalam membuat masalah, ada dua hal yang akan dilakukan yakni menjawab pertanyaan atau berupa hipotesa untuk diuji. Ketika akan melakukan penelitian maka akan berhadapan dengan hal tersebut yakni akan dirumuskan berupa hipotesa atau pertanyaan, atau bahkan keduanya. Tetapi jika keduanya tidak ada maka tentu tidak ada yang namanya penelitian.

Dalam merumuskan pertanyaan ataupun hipotesa sebagaimana dimaksud, akan ada lagi konsepkonsep, maka seorang peneliti harus mengetahui makna-makna dari setiap kata yang ada dalam penelitian tersebut guna menemukan konsep yang sesuai dan cara sebuah penelitian tersebut menjadi lebih dapat dipertanggungjawabkan hasilnya tentu harus mengikuti metode penelitian. Dalam metode penelitian terdapat lagi metode analisis yang akan menganalisis persoalan permasalahan yang sedang diteliti saat itu. Baru kemudian hasil dari analisis yang dibuat dijabarkan dan dipresentasikan sebagai finalisasi dari sebuah penelitian sehingga pasca presentasi akan muncul paradigma baru yang menjawab persoalan yang sudah diteliti sebelumnya. 
Jurnal Filsafat Indonesia, Vol 4 No 2 Tahun 2021

ISSN: E-ISSN 2620-7982, P-ISSN: 2620-7990

\section{d. IImu Pengetahuan dan Agama}

Ketika realitas-realitas yang dapat dinalar itu terukir dalam jiwa yang rasional, maka realitas-realitas itu menjadi ilmu (Al-Ghazali :69). Ilmu pengetahuan tersusun dari kata "ilmu" dan "pengetahuan". Dalam Kamus Besar Bahasa Indonesia (KBBI), ilmu diartikan sebagai pengetahuan atau kepandaian (baik tentang segala yang masuk jenis kebatinan maupun yang berkenaan dengan keadaan alam yang sebenarnya (W. J. S. Poerwadaminta, 1991: 373). Dalam bahasa Arab, kata ilmu jamaknya ulum diartikan ilmu pengetahuan. (W. J. S. Poerwadaminta, 1991: 994). Adapun pengetahuan adalah tahu atau hal mengetahui sesuatu; segala apa yang diketahui; kepandaian atau segala apa yang diketahui atau akan diketahui berkenaan dengan suatu hal. IImu pada hakikatnya berasal dari pengetahuan, namun sudah disusun secara sistematik dan diuji kebenarannya secara ilmiah dan dinyatakan valid atau shahih. Oleh karena itu, maka ilmu pengetahuan adalah pengetahuan yang sudah bersifat ilmiah.

John G. Kemeny dalam Mohammad Adib mengatakan bahwa ilmu dalam arti semua pengetahuan yang dihimpun dengan perantara metode ilmiah (all knowledge by means of the scientific method). (Mohammad Adib, 2010: 49).

Para ahli berusaha menjelaskan tentang sifat dari ilmu pengetahuan yang bersifat ilmiah (scientific) dengan ciri-ciri sebagai berikut.

1) Memiliki objek yang jelas berupa fenomena alam ataupun sosial.

2) Menggunakan metode yang jelas berupa observasi dan eksperimen.

3) Telah disusun secara sistematik dan komprehensif.

4) Rasional, yakni mengandung premis, postulas, preposisi yang masuk akal.

5) Sudah dapat diverifikasi atau dibuktikan kebenarannya di laboratorium.

6) Bersifat universal, yakni bahwa yang ditetapkan dalam teori tersebut dapat digunakan untuk menjelaskan seemua fenomena yang sama, dan diterima semua ahli.

7) Memiliki time response yang jelas.

8) Terikat pada hukum-hukum yang serba pasti.

IImu pengetahuan dengan berbagai macam rumpun, cabang, dan rantingnya hingga kini sudah berkembang sangat luas. Dari berbagai macam ilmu pengetahuan yang muncul, idealnya dapat memberikan dampak positif bagi kehidupan manusia, ilmu pengetahuan diharapkan mampu membimbing manusia untuk dapat berpikiran positif, konstruktif, holistik, serta dapat digunakan untuk mencerahkan berbagai masalah kehidupan. Dengan begitu, ilmu pengetahuan dapat digunakan untuk mewujudkan rahmat Tuhan di muka bumi, karena sejatinya semua ilmu yang ada adalah dari Tuhan.

IImu pengetahuan mencoba menerangkan gejala-gejala secara ilmiah, tujuannya bukan ingin mencapai hakikat yang paling dasar dari semesta, tetapi hanya menjelaskan gejala-gejala secara nasional. Dalam mengupayakan penjelasan ilmiah, ilmu pengetahuan juga menggunakan metode ilmu pengetahuan sebagai langkah-langkah dalam satu urusan metodologis yang ketat demi mendapatkan penjelasan yang seobjektif mungkin tentang alam semesta. Selain itu, ilmu pengetahuan juga sudah terspesialisasi menjadi disiplin-disiplin ilmu yang seolah satu sama lain tidak ada saling kait mengait. Adapun jenis-jenis ilmu pengetahuan yang banyak diketahui oleh orang adalah ilmu pengetahuan seperti biologi, sosiologi, dan antropologi yang sebenarnya mempelajari objek yang sama yakni manusia. Akan tetapi antara satu sama lain melakukan pendekatan dengan sudut pandang yang berbeda-beda dan khusus. Biologi mengkaji manusia dari sisi fisiologis, sosiologi dari sisi hidup bermasyarakat, dan antropologi dari sisi kebudayaan (Donny Gahral Adian, 2011: 20).

Secara epistemologi, ilmu memiliki makna bahwa sesungguhnya dari realitas, bentuk, mode, kuantitas, substansi, dan esensi sesuatu oleh jiwa dengan rasional yang tenang (al-nafs al-natiqah almuthma'innahi). Jadi, subjek atau al-'alim adalah dia yang mengetahui dan menangkap serta memahami, sedangkan objek atau al-ma'lum adalah esensi sesuatu, yang ilmunya terukir di dalam jiwa dan dalam kitab al-risalah al-laduniyyah. (Al-Ghazali ).

Dalam alqur'an terdapat sekitar 800an ayat yang menjelaskan tentang alam semesta, terdapat 200 lebih ayat yang menjelaskan tentang hukum fiqh, dan dari ayat-ayat tersebut saat ini begitu banyak bukubuku yang diterbitkan oleh para ulama, dan para ilmuan muslim membahas, mengkaji serta menganalisis dari kandungan ayat-ayat dalam alqur'an. Hal tersebut menandakan bahwa perhatian umat muslim terhadap ilmu pengetahuan sangat tinggi. Kecintaan terhadap ilmu pengetahuan yang tidak sekadar bercerita tetapi mampu menghasilkan karya-karya tertentu. Dari sekian banyak para ilmuan muslim dengan karya mereka yang luar biasa, terdapat sepuluh ilmuan yang mendapatkan penghargaan nobel untuk bidang sains. Hal tersebut menandakan bahwa dunia mengakui tentang kebenaran dari sebuah ilmu yang bersumber dari alqur'an, karena memang teruji secara ilmiah terhadap apa yang disampaikan oleh alqur'an sejalan dengan hasil penelitian yang sudah dilakukan. Dari karya-karya tersebut tidak menutup kemungkinan dapat menjadi ilham para ilmuan Barat untuk ikut melakukan pengkajian yang 
mendalam tentang makna yang terkandung dalam alqur'an.

Para ilmuan barat juga banyak mempelajari alqur'an sebagai sumber ilmu pengetahuan untuk menjawab pertanyaan dan/ atau hipotesa dari sebuah penelitian yang sedang dilakukan. Menariknya, tidak sedikit para ilmuan Barat menemukan fakta-fakta ilmiah yang ada pada Alqur'an dan sudah diturunkan sejak 1400 tahun yang lalu. Hal itu membuat ilmuan Barat semakin tertarik untuk mengkaji alqur'an bukan dalam hal aqidah maupun hukum Islam itu sendiri, tetapi untuk mencari isyarat-isyarat untuk mengembangkan ilmu pengetahuan agar dapat menemukan penemuan-penemuan baru yang tidak terbantahkan.

Terkait dengan perkembangan ilmu pengetahuan, di Indonesia baik disadari maupun tidak disadari, masih terjadi dikotomi antara ilmu agama dan ilmu umum. Bahkan masih ada yang mengatakan ilmu agama adalah ilmu akhirat sedangkan ilmu umum adalah ilmu dunia ( K.H. Salahudin Wahid). Padahal jika ditelaah lebih mendalam, semua bergantung pada niat seseorang dalam memahami sebuah ilmu tersebut. Jika la mempelajari ilmu agama untuk dirinya sendiri, tidak ada untuk kemaslahatan umat bahkan menjadikan ilmu agama sebagai alat untuk urusan dunia, maka la akan menjadi ilmu dunia. Sebaliknya seperti ilmu fisika, kimia, dan lain-lainnya yang semula dianggap ilmu umum serta tidak ada kaitannya dengan agama jika dalam proses mendapatkannya dengan niat untuk kemaslahatan umat/ orang banyak, membantu orang lain dari ancaman kesehatan dengan niat karena Allah, bisa la menjadi ilmu akhirat. Dari sanalah mengalir pahala sebagai amal jariyahnya karena telah menolong orang lain dengan niat karena Allah, dan semua kebaikan senantiasa melibatkan Allah SWT.

\section{e. Worldview Islam Sebagai Paradigma}

Pada tahun 1880 sekitar abad ke 19, Nietzcche menyatakan bahwa budaya Barat telah berada di pinggir jurang kehancuran. Hal tersebut disebabkan oleh sikap yang terlalu mendewakan rasio, dan pada tahun 1990 Capta menyatakan budaya Barat telah hancur karena terlalu mendewakan rasio (Ahmad Tafsir, 2017: 79).

Sebelum abad 20, ilmuan professor anatomi dan biologi sel di salah satu universitas beserta beberapa ilmuan lainnya, kesulitan melakukan penelitian tentang perkembangan janin karena selain keterbatasan teknologi juga tidak ada satupun literatur yang menjelaskan tahap perkembangan janin. Sementara dalam alqur'an telah ada menjelaskan tentang proses perkembangan janin jauh sebelum adanya teknologi sebagaimana diabadikan dalam surah al-mu'minuun ayat 12-14 tersebut. Atas penemuan tersebut ditulislah suatu karya buku yang diberi judul Human Development as Described in the Alqur'an and Sunnah (2000). Tidak cukup sampai di sana, penemuan ilmuan tersebut mampu membawa ilmuan Keith L. Moore kemudian memeluk agama Islam.

Pada abad ke 20, seorang embriolog melakukan penelitian tentang perkembangan manusia dari tahap ke tahap dimulai dari perkembangan embrio dalam rahim. Hingga sampai pada suatu hari, ilmuan menemukan beberapa ayat dalam alqur'an yang berkaitan dengan apa yang sedang diteliti saat itu. Ayat tersebut menyinggung secara rinci tentang tahap perkembangan zigot hingga menjadi janin. Ayat yang dimaksud ialah Q.S al-mu'minun ayat 12-14 yang berbunyi "dan sesungguhnya Kami telah menciptakan manusia dari suatu saripati (berasal) dari tanah. Kemudian kami jadikan saripati itu air mani (yang disimpan) dalam tempat yang kokoh (rahim). Kemudian air mani itu kami jadikan segumpal darah, lalu segumpal darah itu kami jadikan segumpal daging, dan segumpal daging itu kami jadikan tulang belulang, lalu tulang belulang itu kami bungkus dengan daging. Kemudian kami jadikan dia makhluk yang (berbentuk) lain. Maka Maha Suci Allah pencipta yang paling baik. Awalnya ilmuan mengalami kesulitan untuk memahami ayat tersebut, namun pada saat itu la di bantu oleh kerajaan Arab Saudi untuk menerjemahkan makna yang terkandung dalam ayat tersebut yang sejalan dengan penelitian yang dilakukan, hingga kemudian muncullah konsep embriologi modern.

Terhadap peristiwa yang diuraikan di atas, kita sebagai umat Islam tentunya merasa sangat bahagia, dan bahkan mampu meningkatkan keimanan kepada Allah SWT, karena alqur'an yang selama ini menjadi pedoman hidup umat muslim semakin teruji kebenarannya dari hasil penemuan-penemuan yang empiris oleh para ilmuan meskipun ilmuan yang menemukan bukanlah dari para ilmuan muslim.

Penemuan di atas adalah salah satu dari sekian banyak temuan-temuan para ilmuan yang mengungkapkan kebenaran alqur'an. Dari penelitian tentang sesuatu yang ada dalam tubuh manusia seperti proses perkembangan janin, sampai pada penelitian luar angkasa. Dulu orang akan menganggap bisa sampai keluar angkasa adalah suatu hal yang mustahil, tetapi hari ini hal tersebut menjadi suatu aktivitas biasa para ilmuan yang ingin terus menerus melakukan penelitian terhadap aktivitas luar angkasa.

Menurut pandangan Islam, kebenaran agama Islam menjadi sumber motivasi pengembangan ilmu (M. Arifin, 1995: 131). Agama Islam yang bersumberkan Al-Qur'an dan hadist mengajarkan dan mendidik manusia untuk beripikir dan menganalisis tentang unsur kejadian alam semesta beserta isinya. Agama telah memberikan ruang lingkup bagi pengembangan ilmu dan teknologi, dan pemikiran bahwa perkembangan ilmu dan teknologi jangan sampai menjauh apalagi menghapus peran agama di dalamnya 


\section{(M. Arifin, 1995: 11-12).}

IImu pengetahuan terus berkembang dan para ilmuan terus melakukan penelitian ilmiah untuk memunculkan paradigma baru. Ditambah lagi kecepatan dan kecanggihan teknologi juga ikut berperan penting terhadap berkembangnya suatu keilmuan, jika dulu seseorang yang terpisah oleh jarak jauh tidak bisa saling melihat dan mendengar, kini dengan alat teknologi seperti laptop dan gawai, jarak tidak lagi menjadi penghalang satu sama lain untuk tetap dapat berkomunikasi secara audio dan visual. Jika dulu ada orang yang bisa berbicara satu sama lain dalam jarak yang jauh mungkin dianggap suatu hal yang mustahil, magic, ataupun sulap, tetapi dengan berkembangnya keilmuan membuat sesuatu yang tadinya tidak empiris menjadi empiris.

\section{f. Problematika IImu Umum dan Agama}

Di balik kesuksesan sebuah ilmu pengetahuan, tidak terlepas juga dari problematika yang ada, dan penyebabnya bisa dari banyak faktor. Pada dasarnya banyak terjadi problematika dalam ilmu pengetahuan ada yang bersumber dari ilmuan, proses menemukan fakta ilmiah, dan bisa juga faktor tersebut berasal dari suatu ilmu pengetahuan. Namun pada pembahasan ini peneliti mengambil problematika yang paling menonjol yaitu dikotomi/ pemisahan antara ilmu agama dan ilmu umum.

Perdebatan dan ketidaksepakatan antara muslim reformis, modernis, dan ortodoks satu dengan yang lain tentang masalah Islam dan sains turut mewarnai problematika ilmu pengetahuan, terutama masalah mendasar yakni sains adalah upaya skuler dengan karakter skuler dan sains tidak mengakui eksistensi sang llahi (Pervet Hoodbhoy, 1997: 2).

Terjadi dikotomi ketat antara ilmu agama yang diajarkan di pesantren-pesantren (terutama salafiyah) dikembang dan terus dipertahankan sejak zaman penjajah, dan pada saat itu pula ilmu skuler dari Barat berusaha untuk masuk ke pendidikan negara-negara Islam dengan cara yang tidak manusiawi, seperti menguras kekayaan alam, merusak mental, merendahkan harkat dan martabat orang Islam dan lain sebagainya. Hal tersebut menyebabkan timbulnya rasa kebencian oleh umat Islam terhadap skuler barat dan menganggap semua hal yang datang dari Barat seperti cara berpakaian, teknologi, dan termasuk ilmu pengetahuan adalah haram. Adapun dalil yang digunakan adalah man tasyabbaha bi qaumin fa huwa minhum (barang siapa yang menyerupai suatu kaum maka la termasuk kaum tersebut).

Pada sekitar abad ke-13 sampai abad ke-19 umat Islam mengalami kemunduran dan Barat berusaha memanfaatkan kesempatan tersebut untuk mengembangkan ilmu pengetahuan yang telah dipelajarinya dari Islam sehingga mencapai masa renaisans. Akibatnya ilmu pengetahuan umum kian berkembang pesat sedangkan ilmu pengetahuan Islam masih mengalami kemunduran dan munculah dikotomi ilmu pengetahuan. (Ayi Sofyan, 2010: 244).

Menjelang akhir abad ke 20, karya-karya dari ilmuan muslim sepi dari publik. Hal tersebut disebabkan oleh kritikan Al-Ghazali terhadap seorang filsuf muslim Ibnu Rusyd, akibatnya tokoh-tokoh muslim yang produktif membuat karya mengalihkan pandangan ke yang lainnya. Hingga kemudian muncul komentar dari para tokoh orientalis yang mengatakan bahwa kegiatan intelektual Islam sudah mati (Bagus Takwin, 2018: 109). Tetapi setelah itu, tepatnya 80 (delapan puluh) tahun setelah wafatnya Al-Ghazali, lahir seorang filsuf muslim di dunia Barat yang tidak lain adalah Ibnu Rusyd (Ayi Sofyan, 2010: 255).

Melihat problematika yang terjadi, jika berpikir secara bijaksana tentu bukanlah suatu cara yang baik karena berlandaskan kebencian lalu kemudian mengharamkan semua yang bersumber dari Barat. Padahal, belum tentu semua yang berasal dari Barat adalah buruk atau bahkan haram sebagaimana dikatakan, dan juga tidak semua yang bersumber dari Barat itu baik. Oleh karena itu sejatinya sebagai umat Islam harus mampu menyaring dan menerima setiap sesuatu yang bersumber dari Barat. Tidak hanya berpendapat sepihak lalu menyimpulkan baik semuanya atau buruk semuanya apa lagi disebabkan faktor kebencian atas penjajahan yang kejam. Memandang itu semua, atas peristiwa tersebut, Islam memiliki perspektif sendiri yakni bahwa antara Barat dan juga Timur semua adalah milik Allah, maka baik atau buruknya sesuatu tidak dapat ditentukan oleh tempat. Belum tentu yang berasal dari Timur semua adalah baik atau semua adalah buruk. Sebagaimana firman Allah surat Al-Baqarah ayat 177 yang artinya, "bukanlah menghadapkan wajahmu ke arah Timur dan ke Barat itu suatu kebajikan, akan tetapi sesungguhnya kebajikan itu ialah beriman kepada Allah, hari kemudian, malaikatmalaikat, kitab-kitab, nabi-nabi, dan memberikan harta yang dicintainya kepada kerabatnya, anak-anak yatim, orang-orang miskin, musafir (yang memerlukan pertolongan) dan orang-orang yang memintaminta; dan (memerdekakan) hamba sahaya, mendirikan sholat, dan menunaikan zakat, dan orang-orang yang menepati janjinya apabila ia berjanji dan orang-orang yang sabar dalam kesempitan, penderitaan, dan dalam peperangan. Mereka itulah orang yang benar (imannya), dan mereka itulah orang-orang yang bertakwa".

Terjadinya kesenjangan yang melanda dunia Barat dan dunia Islam merupakan permasalahan yang harus dipecahkan, apalagi saat ini telah banyak dari Barat mengakui dan mengatakan perlunya orang pintar dan baik, orang yang menguasai ilmu pengetahuan dan juga bermoral. Demikian juga dunia 
Islam, sudah mulai tumbuh kesadaran untuk mengembangkan ilmu dan teknologi (Abuddin Nata, 2018: 5). Hal tersebut terlihat dari lembaga-lembaga pendidikan pesantren saat ini yang sudah tidak anti lagi terhadap teknologi bahkan memasukkan teknologi sebagai suatu kebutuhan dalam dunia pendidikan.

\section{g. Hubungan Ilmu, Agama, dan Seni Dalam Perspektif Pengetahuan, Budaya dan Peradaban}

Terlepas dari cerita dikotomi antara ilmu agama dan ilmu umum yang ketat dengan pandangannya masing-masing, melalui filsuf yang arif dan bijaksana tentu mampu mengintegrasikan keduanya, hingga menjadikan keduanya seperti dua sisi mata uang yang tidak dapat dipisahkan. Hal tersebut sejalan dengan ungkapan "Ilmu tanpa agama buta, agama tanpa ilmu adalah lumpuh" (Albert Einsteins, 2009: 3).

Agama merupakan faktor utama dalam mewujudkan pola-pola persepsi dunia bagi manusia dan persepsi-persepsi tersebut turut memengaruhi perkembangan dunia dan juga sejarah, serta menentukan cara manusia menundukkan dirinya (Bakhtiar, 2012: 235).

Agama dan ilmu memang berbeda, tetapi keduanya memiliki persamaan yakni sama-sama memiliki tujuan memberikan keterangan dan kemudahan bagi manusia. Seperti terjadinya peristiwa gempa bumi, banjir, atau bencana lainnya. Maka agama memandang hal tersebut adalah ujian dari Tuhan Yang Maha Kuasa, dan manusia diminta untuk bersabar dan berpikir atas kebesaran Allah atas peristiwa tersebut dan manusia tentu dapat mengambil hikmah dari peristiwa tersebut, sedangkan menurut ilmu gempa bumi terjadi disebabkan pergeseran lempeng bumi atau tersumbatnya lava gunung berapi. Agama mendorong umatnya untuk menuntut ilmu melalui sumber-sumber ajaran dari agama tersebut. Hampir semua kitab suci menganjurkan umatnya untuk menuntut ilmu sebanyak mungkin, maka itu ilmu dan agama tidak selalu dipandanng dalam konteks yang bersebrangan melainkan keduanya bersinergi untuk memberikan penjelasan tentang suatu hal kepada manusia.

Seni merupakan keindahan, dalam filsafat sering disebut dengan estetika, estetika merupakan teori tentang persepsi dalam arti yang sangat luas dan mencakup semua jenis persepsi kenikmatan dan penderitaan (Sutrisno, 2005: 282). Secara filosofis, Islam adalah seni dan keindahan, contohnya sahabat Rasulullah saw yakni Ummar Bin Khattab, dalam sejarahnya sebelum memeluk agama Islam, Ummar adalah sosok yang dikenal sangat kerass dan tegas sekaligus penantang Islam barisan terdepan. Namun dengan lantunan Alqur'an yang didengarnya secara tidak sengaja, ahirnya makna-makna yang ada dalam surah Thaha kala itu ternyata mampu membawa Ummar memeluk agama Islam.

Jika dilihat dari sudut filsafat integralitas atau keterpaduan dengan antara Islam sebagai ajaran keselamatan dan cinta sebagai hakikat keindahan, maka seni adalah eksistensi agama itu sendiri. Rasulullah sendiri juga pernah mengatakan bahwa Islam itu indah. Meski demikian, tidak dapat dipungkiri bahwa seni adalah sesuatu yang bersifat abstrak tetapi memiliki nilai keindahan ataupun estetika yang besar pengaruhnya bagi kehidupan.

Ketika melihat keterkaitan satu sama lain antara ilmu, seni, dan agama, lalu apa hubungannya terhadap ilmu pengetahuan, kebudayaan dan peradaban? Sedikit sudah disinggung pada pembahasan sebelumnya, bahwa ilmu merupakan pengetahuan, dan penngetahuan merupakan unsur kebudayaan. Sehingga ilmu dan kebudayaan berada pada satu sisi yang saling tergantung dan memengaruhi. Kemudian seni merupakan penggerak dari budaya peradaban karena seni merupakan kreativitas manusia yang dapat menghasilkan rasa, seni juga merupakan sistem nilai. Kemudian agama akan mengkritik seni, budaya dan juga ilmu karenanya agama tidak hanya sebatas suatu aktivitas spiritual saja melainkan ikut melakukan transformasi sosial dalam kehidupan.

\section{Simpulan dan Saran}

Sampai pada kesimpulan bahwa paradigma keilmuan Islam berbicara tentang cara para ilmuan mampu mengintegrasikan antara ilmu agama dengan ilmu umum tanpa ada sekatan keduanya yang signifikan. Hal tersebut semakin diperkuat dengan telah dipadu dan ditemukan fakta-fakta ilmiah yang mampu mengaitkan keduanya, seperti peristiwa proses ilmuan mencari fakta tentang perkembangan janin di dalam kandungan yang pada akhirnya membenarkan firman Allah dalam alqur'an setelah menempuh penelitian yang panjang. Masih sangat banyak fakta-fakta dari peristiwa yang lain yang hari ini tidak lagi menjadi rahasia pada kalangan ilmuan maupun umat Islam umumnya.

Kemudian, kata sifat keilmuan lebih mencerminkan hakikat ilmu dari pada istilah ilmu sebagai kata benda, hakikat keilmuan ditentukan oleh cara berpikir yang dilakukan menurut persyaratan keilmuan. kegiatan ilmu juga dinamis (berubah-ubah), seiring dengan aktivitas ilmuan dalam mencari dan menemukan kebenaran dari sebuah fakta ilmiah.

Implikasi dari penelitian ini bahwa Ilmu, agama, seni, pengetahuan, budaya, dan peradaban memiliki hubungan yang sangat erat satu sama lain. Dalam suatu waktu la bisa menjadi topik yang berbeda-beda, namun adakalanya satu sama lain bertemu dan saling keterkaitan. Hal tersebut biasa terjadi dalam kehidupan manusia, bahkan beriringan dengan segala aspek kehidupan. Ilmu pengetahuan yang berusaha menjelaskan tentang suatu hal lalu kemudian di ekspresikan oleh seni dan di kritisi serta 
diperjelas oleh Agama, begitu terjadi secara terus menerus dalam kehidupan, kebudayaan, serta keberadaban manusia.

\section{Daftar Pustaka}

Al-Qur'anul Karim.2006. Maghfirah Pustaka, Jakarta.

Abdul, Rosyid. 2020. "Pergeseran Paradigma Agama dan Sains di Tengah Pandemi Covid dalam Kacamata Thomas Kuhn". Jurnal Asketik: Agama dan Perubahan Sosial. Vol. 4 (2).

Abdul, Aziz. 2013. "Paradigma Integrasi Sains dan Agama Upaya Transformasi IAIN Lampung ke arah UIN". Jurnal Al-AdYaN. Vol.VIII (2).

Abdul, Halik. 2016. "Paradigma Pendidikan Islam Dalam Transformasi Sistem Kepercayaan Tradisional". Jurnal Studi Pendidikan Al-Ishlah. Vol. XIV (2).

Adib, Mohammad. 2010. Filsafat Ilmu: Ontologi, Epistimologi, Aksiologi, dan Logika Ilmu Pengetahuan. Pustaka Pelajar: Yogyakarta.

Adian, Gahral Donny dkk. 2011. Pengantar Filsafat IImu Pengetahuan.

Ahmad, Ali Ryadi. 2018. "Paradigma Problema Keilmuan Islam dan Dampaknya terhadap Model Lembaga Pendidikan Islam di Era Kontemporer". Jurnal Sumbula. Vol. 3 (2).

Arifin, M. 1995. Agama, Ilmu, dan Teknologi. Jakarta: Golden Terayon Press.

Arbi, Imam Hanafi, Munzir Hitami, Helmiati. 2018. 'Model Pengembangan Pparadigma Integrasi IImu di Universitas Islam Negeri Sunan kalijaga Yogyakarta dan Universitas Islam Negeri Maulana Malik Ibrahim Malang, PROFETIKA". Jurnal Studi Islam. Vol. 20 (1).

Ayi, Sofyan Ayi. 2010. Kapita Selekta Filsafat. Pustaka Setia.

Bakhtiar, Amsal. 2012. Filsafat Ilmu. PT. Raja Grafindo Persada: Jakarta.

Darwis, A. Soelaeman. 2019. Filsafat Ilmu Pengetahuan Persefektif Islam dan Barat. Bandar Publishing: Aceh.

Dewi, Masyitoh, dkk. 2020. "Amin Abdullah dan Paradigma Integrasi Interkoneksi". JSSH P-ISSN:25799088. Vol. 4 (1).

Efrinaldi, Toha Andiko, Taufiqurrahman. 2020. "The Paradigm of Science Integration in Islamic University: The Historicity and Development Pattern of Islamic Studies in Indonesia". Journal MADANIA. Vol. 24 (1).

Endraswara, Suwardi. 2012. Filsafat IImu. CAPS: Yogyakarta.

Fadillah, Tridiani Febrisia. 2019. "Paradigma Al-Qur'an Dalam Tradisi Keilmuan Islam”. Jurnal el-Ghiroh. Vol. XVI (1).

Fahri, Hidayat. 2015. "Pengembangan Paradigma Integrasi IImu: Harmonisasi Islam dan Sains dalam Pendidikan". Jurnal Pendidikan Islam. Vol. 4 (2).

Hoodbhoy, Pervet. 1997. Islam dan Sains. Terj Luqman: Bandung.

Lis, Arifudin. 2016. "Integrasi Sains dan Agama serta Implikasinya terhadap Pendidikan Islam". Jurnal Edukasia Islamika. Vol 1 (1).

Kartina, AM. 2004. "Konsep Ilmu dengan Paradigma Tauhid". Jurnal Al-Qalam. Vol. 21 (102).

Kattsoff, O. Louis. 2018. Pengantar Filsafat. Tiara Wacana Yogya: Yogyakarta.

Khotimah, Khusnul. 2014. "Paradigma dan Konsep IImu Pengetahuan dalam Alqur'an”. Vol. 9 (1).

Kurnia, Sari Wiwaha. 2018. "Epistimologi Paradigma Islam: Studi Pemikiran Zainuddin Sardar, Religious". Jurnal Studi Agama- Agama dan Lintas Budaya. Vol. 3 (1).

Mohammad, Kosim. 2008. "IImu Pengetahuan Dalam Islam Persfektif Filosofi-Historis". Jurnal Tadrîs. Vol. 3 (2).

Muhammad, Nur. 2018. "Paradigma Keilmuan UIN Raden Intan Lampung”. Jurnal Studi Keislaman. Vol. 18 (1).

Nata, Abuddin. 2018. Islam dan Ilmu Pengetahuan. Prenademadia Grup: Jakarta.

Poerwadaminta, W. J. S. 1991. Kamus Besar Bahasa Indonesia. Jakarta, Balai Pustaka.

Philip, Buckley, Irawan. 2015. "The Scientific Paradigm of Islamic Education Management: Phenomenology Perspective". Vol. 2 (1). 
Samuji. 2020. "Perkembang Ilmu Pada Zaman Islam". Jurnal Paradigma. Vol. 9 (1).

Suryasumantri, S. Jujun. 2009. Ilmu dalam Perspektif: Sebuah Kumpulan Karangan Tentang Hakikat IImu. Yayasan Obor Indonesia: Jakarta.

Sun, Choirol Ummah. 2019. "Paradigma Keilmuan Islam di Perguruan Tinggi". Jurnal Humanika, Kajian IImiah Mata Kuliah Umum. Vol. 19 (2).

Sutrisno, Mudji, dkk. 2005. Teks-Teks Kunci Estetika: Filsafat Seni. Galangpress: Yogyakarta.

Tafsir, Ahmad. 2017. Filsafat IImu: Mengurai Ontologi, Epistimologi, dan Aksiologi Pengetahuan. PT Remaja Rosdakarya: Bandung.

Takwin, Bagus. 2018. Filsafat Timur: Sebuah Pengantar ke Pemikiran-Pemikiran Timur. Jalasutra: Yogyakarta.

Thoifah, l'anatut dkk. 2020. IImu Dakwah: Praktis Dakwan Millenial. UMM Press: Malang.

Wahid, Salahudin. 2016. Islam dan Ilmu Pengetahuan. Kompas TV.

Wirawan, I.B. 2012. Teori-Teori Sosial dalam Tiga Paradigma. Prenada Media Grup: Jakarta. 